\title{
Second Generation Antipsychotics (SGAs) in Schizophrenic Patients and Bipolar Disorder: Correlation With Metabolic Syndrome (NCEP ATP III(a))
}

\author{
Consuelo Roldan Menco ${ }^{1}$, Anderson Díaz-Pérez ${ }^{1,2}$ \& Zoraida Barrios Puerta ${ }^{1}$ \\ ${ }^{1}$ Faculty of Health Sciences, Corporación Universitaria Rafael Núñez, Cartagena de Indias, Colombia \\ ${ }^{2}$ Faculty of Health Sciences, Universidad Popular del César, Valledupar, Colombia \\ Correspondence: Consuelo Roldan-Menco, Faculty of Health Sciences, University Corporation Rafael Núñez, \\ Cartagena, Colombia. Tel: 57-313-562-2595. E-mail: consueloroldan@curnvirtual.edu.co
}

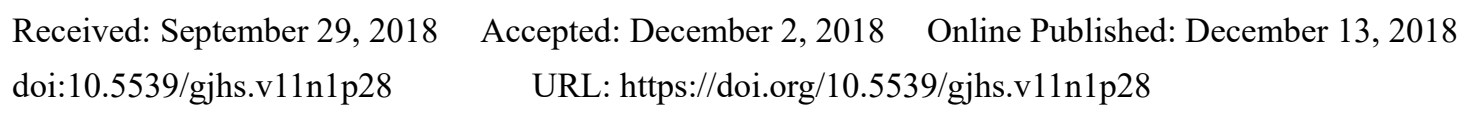

\begin{abstract}
Introduction: The Metabolic Syndrome is a set of diverse clinical situations such as diabetes mellitus, hypertension and dyslipidemia. Patients with mental illnesses such as schizophrenia or bipolar disorder have a higher mortality than the general population attributable in $60 \%$ to somatic diseases and metabolic syndrome, where second generation antipsychotics increase the risk of weight gain and insulin resistance. Objectives. Correlate the treatment with second generation antipsychotics (SGAs) as a possible predictor for Metabolic Syndrome according to the NCEP ATP III (a) classification.
\end{abstract}

Methods: Descriptive, cross-sectional correlational study. The sample was of 92 patients, applying an open and convenience sampling due to the mental state of the patients in order to determine their degree of acceptance to the study (Informed Assent) and consent to the legal guardian as the main inclusion criterion. For the analysis, the following variables were considered: blood pressure, weight, height, abdominal circumference, serum levels of triglycerides, glucose and high density lipoproteins. The SPSS $20.0 \AA$ program was used logistic regression analysis with a p-value $<0.05$ and a confidence level of $95 \%$.

Results: SGAs most used was clozapine (54.3\%). The correlation analysis showed that sociodemographic aspects such as personal history, habits, physical activity and paraclinical and anthropometric records correlated with the possible diagnosis of metabolic syndrome $(\mathrm{p}<0.05)$, but not with SGAs $(\mathrm{p}>0.05)$. ).

Conclusion: No correlation was found between the presence of the metabolic syndrome and the type of antipsychotic treatment.

Keywords: second generation antipsychotics, schizophrenic patients, bipolar disorder, metabolic syndrome

\section{Introduction}

The Metabolic Syndrome (MS) is a current disscusion and issue in the medical community; Its approach is essential because it is related to the diseases that cause the highest mortality worldwide, and its incidence is increasing, characterized by the presence of a set of risk factors such as insulin resistance and compensatory hyperinsulinism associated with disorders of the metabolism of carbohydrates and lipids, high blood pressure levels, and obesity (Menco \& Pérez, 2011; Pineda, 2008)

The adoption of behavioral patterns such as unhealthy diet and lack of physical activity have contributed to the high prevalence of hypertension, hypercholesterolemia, diabetes, obesity, and, with this, that cardiovascular diseases are the leading cause of death, disability and premature mortality (Lakka et al., 2002; Park \& Lee, 2018). The National Cholesterol Education Program Adult Treatment Panel III (ATPIII), implemented some parameters where three or more of the following criteria must be met: high abdominal perimeter $(>102 \mathrm{~cm}$ in men and $>88 \mathrm{~cm}$ in women) TG $>150 \mathrm{mg} / \mathrm{dl}$, Low HDL (men $<40 \mathrm{mg} / \mathrm{dl}$ and women HDL $<50 \mathrm{mg} / \mathrm{dl}$ ), BP $>130 / 85 \mathrm{~mm} \mathrm{Hg}$ or receive antihypertensive therapy, glycemia $>110 \mathrm{mg} / \mathrm{dl}$ including DM, but in 2004 with the update of the American Diabetes Association, glycemia was modified to $100 \mathrm{mg} / \mathrm{dL}$ (Expert Panel on Detection, 2001; Kavey et al., 2003; Grundy et al., 2004). The updated definition of ATPIII (ATPIIIa) is used as the limit of abdominal perimeter the same proposed in the guidelines of the International Diabetes Federation (IDF) for South Americans, that is, $90 \mathrm{~cm}$ 
for men and $80 \mathrm{~cm}$ for women (Alberti, Zimmet, \& Shaw, 2006).

Patients with severe mental illnesses such as schizophrenia or bipolar disorder have a higher mortality 2-3 than the general population (Atun et al., 2015; De Hert, Dekker, Wood, Kahl, \& Möller, 2009; Levav, Lima, Somoza Lennon, Kramer, \& Salvatierra-González, 1989), where according to Newcomer, it is $60 \%$ attributable to somatic diseases and metabolic syndrome (Newcomer, 2007a, 2007b). Regarding the metabolic syndrome, the prevalences are two to four times higher than the rest of the population, in the United States, it has been calculated that the average number of years potentially lost in patients with mental illness ranges from 25 to 30 years, compared with the general population where the main cause of death was coronary heart disease (McEvoy et al., 2005; Cortés Morales, 2011; Vancampfort et al., 2015). It is clear that genetic factors and lifestyle have an influence at mental illnesses as well as the presence of metabolic syndrome, where it has not been possible to elucidate in how the interaction of antipsychotic drugs interact with each other, which Somehow, it would explain the differences in the fact that people with mental illness have a greater predisposition to this type of metabolic diseases (Firmann et al., 2008; De Hert et al., 2009; García-García et al., 2008; McEvoy et al., 2005; Muñoz-Calero Franco et al., 2015; Ortiz Lobo \& Ibáñez Rojo, 2011; Rojo, Mesa, \& Martínez-Ortega, 2014; Lakka et al., 2002).

Second generation antipsychotics (SGAs), as a group can reduce the risk of producing extrapyramidal side effects and hyperprolactinemia when compared with first generation antipsychotics (FGAs) (Martínez, León, Torres, \& Crossley, 2017; Cortés Morales, 2011; Pato, Rodríguez, \& Valverde, 2017). However, there is scientific evidence suggesting that the interaction of these may increase the risk of significant weight, insulin resistance metabolic homeostasis, hyperglycemia, diabetes mellitus (DM) type 2 and dyslipidemia which could reduce life expectancy in patients who need these drugs as schizophrenic patients and with bipolar disorder (Cortés Morales, 2011).

MS is very frequent in patients with severe mental illnesses, several studies have raised the relationship of schizophrenia with MS, consequently in 240 Canadian subjects showed figures of $42.6 \%$ for men and $48.5 \%$ for women using the criteria of the National Cholesterol Education Program ATP (ATP III) (Cortés Morales, 2011). In another study conducted with 430 chronic schizophrenic patients in Belgium the presence of MS reached prevalences of $28.4 \%$, and $36 \%$, according to the diagnostic criteria of the ATP III and the International Diabetes Federation, respectively, being more prevalent in female patients (Moreno, González, Fleta, \& Pérez, 2006). In Latin America, a study conducted in Brazil also found a higher proportion of women using the criteria of the ATP III (Cortés Morales, 2011).

The objective of the study is correlate the treatment with second generation antipsychotics (SGAs) as a possible predictor for Metabolic Syndrome according to the NCEP ATP III (a) classification.

Objetivo del estudio es correlacionar el tratamiento con antipsicóticos de segunda generación (AP2G) como posible factor predictor para Síndrome Metabólico según la clasificación NCEP ATP III(a).

\section{Methods}

Descriptive study with a cross-sectional correlational component. The population was 200 inpatients and outpatients of a psychiatric center of the City of Cartagena de Indias/Colombia. The method of sample selection was opened for convenience, for a $(\mathrm{n}=92)$ outcome of patients with schizophrenia and bipolar disorder.

The participating patients gave their informed consent as a way to contribute to their moral development (Autonomy), informed consent was given to the tutors and to patients who demonstrated maturity and independence in the adherence of the treatment as the main inclusion criterion, as a suggestion of the ethics committee of the Corporación Universitaria Rafael Núñez, in addition the patient's data was processed and safeguarded subject to Resolution 8430 of 1993 of Colombia and to the declaration of Helsinki. As exclusion criteria, patients who were not medicated with (SGAs) and patients under 18 years of age did not participate due to the conditions of their mental capacity in relation to the type of pathology.

An instrument validated by experts was applied, in order to obtain sociodemographic, clinical and risk factors information, antipsychotic treatment, cardiovascular and family risk history, among others. Anthropometric parameters were taken, as well as blood sampling. The body mass index (BMI) was calculated by using the measured anthropometric parameters: weight in kilograms and height in meters $\left(\mathrm{Kg} / \mathrm{m}^{2}\right)$. Likewise, the measurement of the abdominal and hip circumference was made in centimeters with a tape measure, the blood pressure measurement was made using a mercury sphygmomanometer with the patient sitting after five minutes of rest according to the indications of the British Hypertension Society (Williams et al., 2004; Stergiou et al., 2018).

Within the paraclinical studies venipuncture was performed, with a fasting period of 12 hours, to evaluate glucose, total cholesterol, HDL cholesterol and triglycerides. LDL cholesterol was determined by the Friedewald formula. The determinations were made using Fotometer Humalyzer primus (HUMAN), with human serum control level I 
and II. For the analysis of the metabolic syndrome, the criteria of (NCEP ATP-III (a)) were considered, considering three or more of the following criteria: abdominal obesity (waist circumference $\geq 90 \mathrm{~cm}$ in men and $\geq 80 \mathrm{~cm}$ in women; 2) Triglyceride values greater than or equal to $150 \mathrm{mg} / \mathrm{dl}$, c-HDL values $<40 \mathrm{mg} / \mathrm{dl}$ in men and $<50 \mathrm{mg} / \mathrm{dl}$ in women; 3) values of blood pressure greater than or equal to $130 / 85 \mathrm{mmHg}$ or carry hypertensive treatment; 4) values of plasma glucose of greater than or equal to $100 \mathrm{mg} / \mathrm{dl}$ in the fasted state (including diabetes mellitus) (Thomas et al., 2005; Heng et al., 2006). Through the SPSS 20.0® for Windows, the univariate and multivariate logistic regression analysis was performed. All calculations were made with a $95 \%$ confidence level and p-value $<0.05$.

\section{Results}

The population was constituted by women $(n=44)$ and men $(n=48)$ in equal proportion, between ages of 18 to 76 years with an average of 35.5 years, the great majority are young adults with ages of 23 years ( $7.6 \%$ ). (Table 1$)$

Table 1. Age

\begin{tabular}{ll}
\hline Sample & $\mathbf{9 2}$ \\
\hline Mean & 38,62 \\
Standard error of the mean & 1,590 \\
Median & 35,50 \\
Mode & 23 \\
Standard deviation & 15,252 \\
Variance & 232,634 \\
Rank & 58 \\
Minimum & 18 \\
Maximum & 76 \\
\hline
\end{tabular}

In women, a greater distribution of mental illnesses was found in relation to bipolar disorder in a (36.4\%). In men the highest percentage was found in schizophrenia compared to women in a $(72.9 \%)$, however no statistical significance was found between the distribution of the disease between the sexes (P-value $>0.05$ ). (Table 2)

Table 2. Gender versus Diagnosis

\begin{tabular}{|c|c|c|c|c|c|c|c|c|c|}
\hline & & \multicolumn{6}{|l|}{ Diagnosis } & \multirow[b]{2}{*}{$\begin{array}{l}\text { Total } \\
\text { n (\%) }\end{array}$} & \multirow[b]{2}{*}{$\begin{array}{l}P \\
\text { Value }\end{array}$} \\
\hline & & $\begin{array}{l}\text { Schizophrenia } \\
\mathrm{n}(\%)\end{array}$ & $\begin{array}{l}\text { Asperger } \\
\text { Syndrome } \\
\mathrm{n}(\%)\end{array}$ & $\begin{array}{l}\text { Bipolar } \\
\text { Disorder } \\
\mathrm{n}(\%)\end{array}$ & $\begin{array}{l}\text { Mental disorder } \\
\text { (Behavior) } \\
\mathrm{n}(\%)\end{array}$ & $\begin{array}{l}\text { Mixed } \\
\text { Disorder } \\
\mathrm{n}(\%)\end{array}$ & $\begin{array}{l}\text { Acute } \\
\text { Psychotic } \\
\text { Disorder } \\
\text { n }(\%)\end{array}$ & & \\
\hline \multirow{2}{*}{ Gender } & Female & $24(54,5)$ & $0(0,00)$ & $16(36,4)$ & $0(0,00)$ & $2(4,5)$ & $0(0,00)$ & $44(100)$ & \multirow{3}{*}{$0,94 *$} \\
\hline & Male & $35(72,9)$ & $1(2,1)$ & $8(16,7)$ & $2(4,2)$ & $0(0,00)$ & $1(2,1)$ & $48(100)$ & \\
\hline Total & & $59(64,1)$ & $1(1,1)$ & $24(26,1)$ & $2(2,2)$ & $2(2,2)$ & $1(1,1)$ & $92(100)$ & \\
\hline
\end{tabular}

Pearson Chi-square*.

In patients diagnosed with Schizophrenia and Bipolar Disorder, it was found a prevalence of sedentary lifestyle, with a high rate of increasing their tendency to obesity, added to the consumption of alcohol and smoking, which also increases the probability of suffering from hypertension at medium term. (Table 3 ) 
Table 3. Habits and Concomitant Diseases versus Schizophrenia and Bipolar Disorder

\begin{tabular}{|c|c|c|c|c|c|c|}
\hline \multirow{4}{*}{ Personal History } & \multicolumn{6}{|c|}{ Pathologies } \\
\hline & \multirow{2}{*}{\multicolumn{2}{|c|}{$\begin{array}{l}\text { Schizophrenia } \\
\mathrm{n}=67(\%)\end{array}$}} & \multirow{2}{*}{\multicolumn{2}{|c|}{$\begin{array}{l}\text { Bipolar Disorder } \\
\mathrm{n}=25(\%)\end{array}$}} & \multirow{2}{*}{\multicolumn{2}{|c|}{$\begin{array}{l}\text { Total } \\
\mathrm{n}=92(\%)\end{array}$}} \\
\hline & & & & & & \\
\hline & Yes & No & Yes & No & Yes & No \\
\hline Hypertension & $8(11.9)$ & $59(88.1)$ & $5(20)$ & $20(80)$ & $13(14.1)$ & $79(85.9)$ \\
\hline Obesity & $13(19.4)$ & $54(80.6)$ & $6(24)$ & $19(76)$ & $19(20.7)$ & $73(79.3)$ \\
\hline Sedentary lifestyle & $45(67.2)$ & $22(32.8)$ & $15(60)$ & $10(40)$ & $60(65.2)$ & $32(34.8)$ \\
\hline Smoker & $14(20.9)$ & $53(79.1)$ & $3(12)$ & $22(88)$ & $17(18.5)$ & $75(81.5)$ \\
\hline Alcohol Consumer & $17(25.4)$ & $50(74.6)$ & $7(28)$ & $18(72)$ & $24(26.1)$ & $68(73.9)$ \\
\hline
\end{tabular}

The correlation found between the possible diagnosis of metabolic syndrome and the presence of schizophrenia in personal history was significant in patients with hypertension, which increases in 4.8 times the risk of presenting metabolic syndrome $(\mathrm{P}$-value $=0.044)$, as well schizophrenic patients with a history of obesity have 3.6 times more risk $(\mathrm{P}$-value $=0.042)$. (Table 4$)$

Meanwhile, the results obtained for the case of bipolar disorder patients were less significant than the sociodemographic factors, only the age of the patient with this disorder was correlated with the presence of the syndrome, in at an older age, greater risk of this in $1.06(\mathrm{P}$-value $=0.044)$. As for the habits related to health and the realization of physical activity, the act of dancing was significant, reducing the risk of metabolic syndrome in $0.125($ P-value $=0.049)$. $($ Table 5$)$

Table 4. Logistic regression between the presence of metabolic syndrome and risk factors present in patients with schizophrenia

\begin{tabular}{|c|c|c|c|}
\hline \multirow{2}{*}{ Dimension } & \multirow{2}{*}{ Variables } & \multicolumn{2}{|c|}{ Schizophrenia } \\
\hline & & Odds Ratio & P-value \\
\hline \multirow{2}{*}{ Personal History } & Hypertension & 4,889 & 0,044 \\
\hline & Obesity & 3,679 & 0,042 \\
\hline \multirow{4}{*}{ Habits and Physical Activity } & Sports & 0,375 & 0,040 \\
\hline & Perform Exercises & 0,267 & 0.019 \\
\hline & Walks & 0,381 & 0,020 \\
\hline & Fleet & 0,333 & 0,020 \\
\hline \multirow{4}{*}{ Nutrition } & Low salt & 0,092 & 0,004 \\
\hline & Fat Consumption & 0,423 & 0,017 \\
\hline & Low in sugar & 0,348 & 0,010 \\
\hline & Consumption of Fruits and Vegetables & 0,407 & 0,012 \\
\hline \multirow{8}{*}{ Anthropometric Paraclinical Records } & Glicemia $(\mathrm{Mg} / \mathrm{Dl})$ & 1,053 & 0,009 \\
\hline & $\operatorname{Hdl}(\mathrm{Mg} / \mathrm{Dl})$ & 0.888 & 0,003 \\
\hline & Triglycerides (mg/dl) & 1,009 & 0,018 \\
\hline & weight(Kg) & 1,074 & 0,001 \\
\hline & $\mathrm{BMI}\left(\mathrm{Kg} / \mathrm{m}^{2}\right)$ & 1,201 & 0,002 \\
\hline & Waist Perimeter & 1,067 & 0,002 \\
\hline & Mean Systolic Pressure & 1,097 & 0,001 \\
\hline & Mean Diastolic Pressure & 1,106 & 0,003 \\
\hline
\end{tabular}




\begin{tabular}{llll}
\hline & Quetiapine & 0,844 & 0,893 \\
Second generation Antipsychotics & Risperidone & 0,711 & 0,591 \\
& Clozapine & 0,030 & 0,747 \\
& Olanzapine & - & - \\
\hline
\end{tabular}

Table 5. Logistic regression between the presence of metabolic syndrome and risk factors in patients with Bipolar Disorder

\begin{tabular}{|c|c|c|c|}
\hline \multirow[b]{2}{*}{ Dimension } & \multirow[b]{2}{*}{ Variables } & \multicolumn{2}{|c|}{ Bipolar Disorder } \\
\hline & & $\begin{array}{l}\text { Odds } \\
\text { ratio }\end{array}$ & P-value \\
\hline Sociodemographic & Age & 1,060 & 0,044 \\
\hline Habits and Physical Activity & Dancing & 0,125 & 0,049 \\
\hline \multirow{3}{*}{ Anthropometric Paraclinical Records } & $\mathrm{HDL}(\mathrm{mg} / \mathrm{dl})$ & 0.752 & 0,029 \\
\hline & Weight(Kg) & 1,121 & 0,038 \\
\hline & Waist Perimeter & 1,075 & 0,029 \\
\hline \multirow{4}{*}{ Second generation Antipsychotics } & Quetiapine & 0,420 & 0,325 \\
\hline & Risperidone & 0,933 & 0,958 \\
\hline & Clozapine & 0,643 & 0,669 \\
\hline & Olanzapine & - & - \\
\hline
\end{tabular}

Finally, it was observed that none of the second generation antipsychotics used as treatment by schizophrenic and bipolar disorder patients affects the risk of presenting metabolic syndrome (P-value $>0.05$ ).

\section{Discussion}

In the correlation analyzes, no statistical significance was found between the metabolic syndrome and the second generation antipsychotics, a similar outcome was presented by Estévez and McEvoy, in whose study in whose study throw non-significant values between the mentioned variables (Estévez et al., 2013; McEvoy et al., 2005). These authors argue that a possible cause for the lack of correlation could be the sample size, which in its case was 53 , while in the present investigation it was also reduced, but with 92 patients.

Another possible cause for this lack of correlation may originate that metabolic syndrome is not necessarily arising from the effect of antipsychotics, at least in patients with bipolar affective disorder, which were considered in their study, but it is a multisystemic and multifactorial disease, clearly develops from other factors (Jaramillo, Mejía, Velásquez, Palacio, \& Zuluaga, 2013). Another study in this regard is that of Almeida et al, cited by Jaramillo, who found that the onset of MS was greater among patients taking lithium than in those taking antipsychotics, which would be a clear indicator that the syndrome is not necessarily related to antipsychotics. At this point it is important to mention that lifestyle also triggers the onset of the syndrome in patients with mental disorders (Jaramillo et al., 2013).

Despite the above, there are studies that do demonstrate the relationship between antipsychotics and the syndrome, in which adverse effects were detected by the use of second generation antipsychotics in patients with chronic schizophrenia, such as weight gain due to the use of olanzapine and from here on with the metabolic syndrome (Aguilar, Coronas, \& Caixàs, 2012; Cortés Morales, 2011; De Hert et al., 2009; Estévez et al., 2013; Jaramillo et al., 2013; McEvoy et al., 2005; Muñoz \& Gallardo, 2004; Newcomer, 2007a, 2007b; Pato et al., 2017; Vancampfort et al., 2015).

Studies mention that there are high possibilities of presenting the syndrome in patients with physical inactivity and an excess of food intake, which promotes weight gain and obesity, in addition, smoking alters the function of insulin. In the study conducted, sedentary lifestyle was one of the most frequent habits, both in bipolar $(60 \%)$ and schizophrenic (67.2\%) (Jaramillo et al., 2013). Patients suffering from schizophrenia, especially those who have long duration of hospitalization have poor quality of life (Choo et al., 2017). Further research is required to assess the relationship between metabolic syndrome and quality of life in patients suffering from schizophrenia. 
Within the personal health history it was found that obesity is present in $19.4 \%$ of schizophrenics and in $24 \%$ of bipolar patients, something similar happens with hypertension, these two conditions, at least in schizophrenic patients, kept relationship with the presence of the syndrome, and they may increase the risk of suffering from it.

From the above it could be thought that the effect of antipsychotics on the development of metabolic syndrome is indirect, because it affects the risk factors that trigger it, but not the syndrome itself. This statement could be supported by studies that recognize that weight gain is a well-documented side effect of antipsychotics during the acute and maintenance treatment of patients with schizophrenia, in this context, the weight gain is maximum with second-generation antipsychotics such as clozapine and olanzapine, in addition the weight gain becomes rapid during the first weeks, slows gradually and often reaches a plateau after one year of treatment (Correll, Detraux, Lepeleire, \& De Hert, 2015; Martinez et al., 2017). The etiology of metabolic syndrome in patients suffering from schizophrenia include genetic factors and inflammation but this study did not measure these biological factors (Ho et al 2014). This is the main limitation of this study.

\section{Conclusion}

Mental illnesses were differentiated according to gender, in male subjects predominated schizophrenia, while in female ones bipolar disorder. A possible low prevalence of metabolic syndrome was observed in both groups of patients. Of particular attention is that patients with risk factors such as weight gain that can lead to different cardiac pathologies that can be exacerbated with the consumption of antipsychotics, especially in the interaction of these.

It is necessary to promote healthy habits and the realization of physical activities at this population, since it was found a protective effect on the risk of suffering from the syndrome in those patients who perform blood pressure checks, carry out exercises, walks, as well as fleets, and dance sessions (especially bipolar subjects), it is recommended to institutionalize at the psychiatric center a program of physical exercise, aerobic by a person or a group of trained people, understanding that among the physiopathology of the SM and mental disorders such as bipolar there are common elements that can exacerbate any of the two pathologies or even both.

Obesity and hypertension were two of the most common conditions among psychiatric patients, and were discussed as elements that increase the risk of the metabolic syndrome.

It is recommended to design a sustainable and feasible diet, in addition to consider for future studies to include various psychiatric entities so that the study has a greater statistical significance.

\section{Financing}

Project financed in internal call of the Corporación Universitaria Rafael Núñez (CURN).

\section{Competing Interests Statement}

The authors declare that there are no competing or potential conflicts of interest.

\section{References}

Aguilar, E., Coronas, R., \& Caixàs, A. (2012). Síndrome metabólico en pacientes esquizofrénicos con tratamiento antipsicótico. Medicina clínica, 139(12), 542-546. https://doi.org/10.1016/j.medcli.2012.05.028

Alberti, K. G. M. M., Zimmet, P., \& Shaw, J. (2006). Metabolic syndrome-a new world-wide definition. A consensus statement from the international diabetes federation. Diabetic medicine, 23(5), 469-480. https://doi.org/10.1111/j.1464-5491.2006.01858.x

Atun, R., De Andrade, L. O. M., Almeida, G., Cotlear, D., Dmytraczenko, T., Frenz, P., ... Muntaner, C. (2015). Health-system reform and universal health coverage in Latin America. The Lancet, 385(9974), 1230-1247. https://doi.org/10.1016/S0140-6736(14)61646-9

Choo CC, Chew PKH, Ho CS, Ho RC. Prediction of Quality of Life in Asian Patients with Schizophrenia: A Cross-sectional Pilot Study. Front Psychiatry, 5(8), 198. https://doi.org/10.3389/fpsyt.2017.00198

Correll, C. U., Detraux, J., Lepeleire, J., \& De Hert, M. (2015). Efectos de antipsicóticos, antidepresivos y estabilizadores del estado de ánimo sobre el riesgo de enfermedades físicas en personas con esquizofrenia, depresión y trastorno bipolar. WPA, 14, 119-136.

Cortés Morales, B. (2011). Síndrome metabólico y antipsicóticos de segunda generación. Revista de la Asociación Espa-ola de Neuropsiquiatría, 31(2), 303-320. https://doi.org/10.4321/S0211-57352011000200009

De Hert, M., Dekker, J. M., Wood, D., Kahl, K. G., \& Möller, H.-J. (2009). Enfermedad cardiovascular y diabetes en personas con enfermedad mental grave: Declaración de la posición de la Sociedad Psiquiátrica Europea 
(EPA), respaldada por la Asociación Europea para el Estudio de la Diabetes (EASD) y la Sociedad Europea de Cardiología (ESC). Revista de Psiquiatría y Salud Mental, 2(1), 49-59. https://doi.org/10.1016/S1888-9891(09)70714-1

Estévez, M. J. V., Domínguez, M. F., Corti-as, M. J. L., Seoane, M. N., Sánchez, E. P., \& Quintas, C. M. G. (2013). Prevalencia del síndrome metabólico en esquizofrenia y trastorno bipolar:?’ sería útil un protocolo de control cardiovascular? Cadernos de atención primaria, 19(4), 215-222.

Expert Panel on Detection, E. (2001). Executive summary of the third report of the National Cholesterol Education Program (NCEP) expert panel on detection, evaluation, and treatment of high blood cholesterol in adults (Adult Treatment Panel III). Jama, 285(19), 2486. https://doi.org/10.1001/jama.285.19.2486

Firmann, M., Mayor, V., Vidal, P. M., Bochud, M., Pécoud, A., Hayoz, D., .. Yuan, X. (2008). The CoLaus study: a population-based study to investigate the epidemiology and genetic determinants of cardiovascular risk factors and metabolic syndrome. BMC cardiovascular disorders, $8(1), 6$. https://doi.org/10.1186/1471-2261-8-6

García-García, E., la Llata-Romero, D., Kaufer-Horwitz, M., Tusié-Luna, M. T., Calzada-León, R., Vázquez-Velázquez, V., ... Velázquez-Fernández, D. (2008). La obesidad y el síndrome metabólico como problema de salud pública. Una reflexión. Acta pediátrica de México, 29(4), 227-245.

Grundy, S. M., Cleeman, J. I., Merz, C. N. B., Brewer, H. B., Clark, L. T., Hunninghake, D. B., ... Program, C. C. of the N. C. E. (2004). Implications of recent clinical trials for the national cholesterol education program adult treatment panel III guidelines. Journal of the American College of Cardiology, 44(3), 720-732. https://doi.org/10.1016/j.jacc.2004.07.001

Heng, D., Ma, S., Lee, J. J., Tai, B. C., Mak, K. H., Hughes, K., .. Tai, E. S. (2006). Modification of the NCEP ATP III definitions of the metabolic syndrome for use in Asians identifies individuals at risk of ischemic heart disease. Atherosclerosis, 186(2), 367-373. https://doi.org/10.1016/j.atherosclerosis.2005.07.020

Ho, C. S., Zhang, M. W., Mak, A., Ho, R. C. (2014). Metabolic syndrome in psychiatry: advances in understanding and management. Advances in Psychiatric Treatment, 20, 101-112. https://doi.org/10.1192/apt.bp.113.011619

Jaramillo, C. L., Mejía, A. C., Velásquez, A. H., Palacio, T. F. R., \& Zuluaga, J. O. (2013). Síndrome metabólico y trastorno afectivo bipolar: una revisión de la literatura. Revista Colombiana de Psiquiatría, 42(3), 283-291. https://doi.org/10.1016/S0034-7450(13)70021-0

Kavey, R.-E. W., Daniels, S. R., Lauer, R. M., Atkins, D. L., Hayman, L. L., \& Taubert, K. (2003). American Heart Association guidelines for primary prevention of atherosclerotic cardiovascular disease beginning in childhood. Circulation, 107(11), 1562-1566. https://doi.org/10.1161/01.CIR.0000061521.15730.6E

Lakka, H.-M., Laaksonen, D. E., Lakka, T. A., Niskanen, L. K., Kumpusalo, E., Tuomilehto, J., \& Salonen, J. T. (2002). The metabolic syndrome and total and cardiovascular disease mortality in middle-aged men. Jama, 288(21), 2709-2716. https://doi.org/10.1001/jama.288.21.2709

Levav, I., Lima, B. R., Somoza Lennon, M., Kramer, M., \& Salvatierra-González, R. (1989). Salud mental para todos en America Latina y el Caribe: bases epidemiologicas para la accion.

Martinez, M. I. V., León, F., Torres, R., \& Crossley, N. A. (2017). Antipsicóticos de primera y segunda generación en esquizofrenia: eficacia, efectividad y efecto de la dosis utilizada. ARS MEDICA Revista de Ciencias Médicas, 42(1), 41-48. https://doi.org/10.11565/arsmed.v42i1.452

McEvoy, J. P., Meyer, J. M., Goff, D. C., Nasrallah, H. A., Davis, S. M., Sullivan, L., ... Lieberman, J. A. (2005). Prevalence of the metabolic syndrome in patients with schizophrenia: baseline results from the Clinical Antipsychotic Trials of Intervention Effectiveness (CATIE) schizophrenia trial and comparison with national

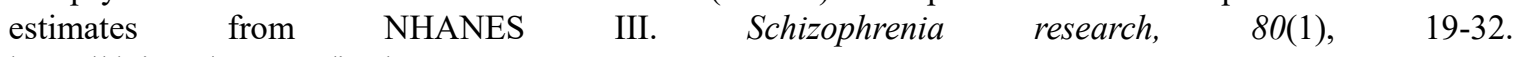
https://doi.org/10.1016/j.schres.2005.07.014

Menco, C. R., \& Pérez, A. D. (2011). Otros factores asociados con síndrome metabólico? Ciencia y Salud Virtual, 3(1), 135-143. https://doi.org/10.22519/21455333.300

Moreno, T. S.-A., González, R. T., Fleta, J. L. H., \& Pérez, P. L. (2006). Alta prevalencia de síndrome metabólico en pacientes esquizofrénicos: una revisión de la literatura. Psiquiatría Biológica, 13(4), 127-135. https://doi.org/10.1016/S1134-5934(06)75353-2

Mu-oz, P., \& Gallardo, R. (2004). Trastornos metabólicos en pacientes esquizofrénicos tratados con Clozapina. 
Revista chilena de neuro-psiquiatría, 42(1), 37-42.

Mu-oz-Calero Franco, P., Sánchez Sánchez, B., Rodríguez Criado, N., Pinilla Santos, B., Bravo Herrero, S., Fourcade, C., ... Martín Aragón, R. (2015). Síndrome metabólico y riesgo cardiovascular en pacientes con diagnóstico de esquizofrenia, trastorno esquizoafectivo y trastorno bipolar. Nutrición Hospitalaria, 32(6), 2715-2717.

Newcomer, J. W. (2007a). Antipsychotic medications: metabolic and cardiovascular risk. The Journal of clinical psychiatry.

Newcomer, J. W. (2007b). Metabolic syndrome and mental illness. The American journal of managed care, $13(7$ Suppl), S170-7.

Ortiz Lobo, A., \& Ibá-ez Rojo, V. (2011). Iatrogenia y prevención cuaternaria en salud mental. Revista Espa-ola de Salud Pública, 85(6), 513-525. https://doi.org/10.1590/S1135-57272011000600002

Park, B., \& Lee, Y.-J. (2018). Metabolic syndrome and its components as risk factors for prolonged corrected QT interval in apparently healthy Korean men and women. Journal of Clinical Lipidology. https://doi.org/10.1016/j.jacl.2018.07.004

Pato, C. M. F., Rodríguez, V. M., \& Valverde, J. I. F. (2017). Síndrome metabólico y antipsicóticos atípicos. Posibilidad de predicción y control. Revista de Psiquiatría y Salud Mental, 10(1), 38-44. https://doi.org/10.1016/j.rpsm.2016.09.003

Pineda, C. A. (2008). Síndrome metabólico: definición, historia, criterios. Colombia médica, 39(1).

Rojo, L., Mesa, F., \& Martínez-Ortega, J. M. (2014). Prevalencia del síndrome metabólico en pacientes espa-oles con esquizofrenia y sobrepeso. El estudio CRESSOB. Actas Esp Psiquiatr, 42(1), 9-17.

Stergiou, G. S., Asmar, R., Myers, M., Palatini, P., Parati, G., Shennan, A., ... Monitoring, E. S. of H. W. G. on B. P. (2018). Improving the accuracy of blood pressure measurement: the influence of the European Society of Hypertension International Protocol (ESH-IP) for the validation of blood pressure measuring devices and future perspectives. LWW. https://doi.org/10.1097/HJH.0000000000001635

Thomas, G. N., Ho, S.-Y., Janus, E. D., Lam, K. S., Hedley, A. J., Lam, T. H., \& Committee, H. K. C. R. F. P. S. S. (2005). The US national cholesterol education programme adult treatment panel III (NCEP ATP III) prevalence of the metabolic syndrome in a Chinese population. Diabetes research and clinical practice, 67(3), 251-257. https://doi.org/10.1016/j.diabres.2004.07.022

Vancampfort, D., Stubbs, B., Mitchell, A. J., De Hert, M., Wampers, M., Ward, P. B., ... Correll, C. U. (2015). Risk of metabolic syndrome and its components in people with schizophrenia and related psychotic disorders, bipolar disorder and major depressive disorder: a systematic review and meta-analysis. World Psychiatry, 14(3), 339-347. https://doi.org/10.1002/wps.20252

Williams, B., Poulter, N. R., Brown, M. J., Davis, M., McInnes, G. T., Potter, J. F., ... Thom, S. M. (2004). Guidelines for management of hypertension: report of the fourth working party of the British Hypertension Society, 2004-BHS IV. Journal of human hypertension, 18(3), 139. https://doi.org/10.1038/sj.jhh.1001683

\section{Copyrights}

Copyright for this article is retained by the author(s), with first publication rights granted to the journal.

This is an open-access article distributed under the terms and conditions of the Creative Commons Attribution license (http://creativecommons.org/licenses/by/4.0/). 